\title{
VIABILITY AND INFECTIVITY OF CERATOBASIDIUM SP. ENCAPSULATED IN ALGINATE BEADS UNDER DIFFERENT STORAGE CONDITIONS
}

\author{
Queenny K. López ${ }^{1}$, Cesar A. Castro ${ }^{1}$, Diana L. Curillo ${ }^{1}$, Eduardo J. Chica ${ }^{1}$, \\ José V. Portilla ${ }^{2}$ \& Denisse F. Peña ${ }^{1,3}$ \\ ${ }^{1}$ Facultad de Ciencias Agropecuarias, Universidad de Cuenca, Campus Yanuncay, \\ Av. 12 de octubre y Diego de Tapia, Cuenca, Ecuador. \\ ${ }^{2}$ Ecuagenera Cia. Ltda., km 2,5 vía Gualaceo-Cuenca, Cuenca, Ecuador. \\ ${ }^{3}$ Author for correspondence: denisse.pena@ucuenca.edu.ec
}

\begin{abstract}
Mycorrhizal fungi are important partners of orchids because they establish close symbiotic relationships with this group of plants, and its preservation is also important for the successful conservation of orchids. In the present study, the conservation of Ceratobasidium sp., a fungal symbiont, using encapsulation in alginate beads was tested over different times, temperatures of storage and dehydrated conditions. Osmotically dehydrated and air-dried beads were stored at room temperature $\left(20 \pm 2{ }^{\circ} \mathrm{C}\right), 4^{\circ} \mathrm{C},-20^{\circ} \mathrm{C}$ and $-80^{\circ} \mathrm{C}$. The fungal growth was verified after 4, 8, 26 and 96 weeks. A second test was carried out to evaluate the encapsulations of fungi as a form of inoculation in Trichoceros antennifer orchid to promote symbiosis and plants development. The results show that the encapsulation of Ceratobasidium in alginate beads is a viable strategy for its conservation, the beads are of easy manipulation and promote plant growth when inoculated in plant substrate. These results may be adopted as part of effective conservation strategies for mycorrhizal fungi and orchids.
\end{abstract}

RESUMEN. Los hongos micorrícicos son socios importantes de las orquídeas ya que establecen relaciones simbióticas estrechas con este grupo de plantas y su conservación es también importante para la conservación de las orquídeas. En este estudio, la conservación de Ceratobasidium sp., un simbionte fúngico, usando encapsulación en perlas de alginato fue evaluada a diferentes tiempos, temperaturas de almacenamiento y formas de deshidratación. Cápsulas secadas al aire y deshidratación osmótica fueron almacenadas a temperatura ambiente $\left(20 \pm 2{ }^{\circ} \mathrm{C}\right), 4{ }^{\circ} \mathrm{C},-20^{\circ} \mathrm{C}$ y $-80{ }^{\circ} \mathrm{C}$. El crecimiento del hongo fue verificado después de $4,8,26$ y 96 semanas. Una segunda prueba fue llevada a cabo para evaluar la encapsulación del hongo como una forma de inoculación para promover la simbiosis y el desarrollo en plantas de la orquídea Trichoceros antennifer. Los resultados sugieren que la encapsulación de Ceratobasidium en perlas de alginato, es una estrategia viable para su conservación, que las perlas son fáciles de manipular y que estimulan el crecimiento cuando se inoculan en el sustrato de las plantas. Este trabajo podría facilitar el diseño de estrategias de conservación de hongos micorrícicos y de las orquídeas asociadas.

Key words/Palabras Clave: alginate encapsulation, encapsulación en alginato, Ceratobasidium sp., symbiotic fungal, hongos simbióticos, Trichoceros antennifer

Introduction. More than $85 \%$ of orchids in the world are in at least one category of endangerment (Wraith \& Pickering 2018). Despite Orchidaceae being the most diverse family of vascular plants globally, they face various conservation problems (Reiter et al. 2016): climate change, habitat loss, unregulated extraction and the complexity of biotic and abiotic conditions necessary for their development, constitute the main threats (Swarts \& Dixon 2009). Precisely, complex close symbiotic relationships between orchids with fungi, is one of the determining factors that guarantees the early seedling development (Sommerville et al. 2008). Endophytic fungi, both mycorrhizal and non-mycorrhizal, actively participate in the cycling of carbon (C), nitrogen $(\mathrm{N})$, phosphorus $(\mathrm{P})$, and increase the productivity and diversity of plants (van der Heijden et al. 2015) and help supply the reserve-depleted orchid seeds with carbohydrates (Suárez \& Kottke 2016). Consequently, there is a need to develop tools that link the activity of mycorrhizal fungi with their orchid hosts, to guarantee 
biological interactions, ecological stability and favorable growth for both organisms that could in turn support their conservation (Teixeira da Silva et al. 2015).

Traditionally, ex situ conservation of orchids has relied on long-term storage of seeds at low temperatures, being this, the quintessential method for preservation (Jiang et al. 2017). However, there is generally no included symbiotic microorganisms (Wood et al. 2000), which undoubtedly presents ecological limitations and reduces the probability of survival when plants are reintroduced.

Fungi, including orchid symbionts, have been traditionally preserved in specific media culture, which face contamination risk, and morphological and physiological mutations. Another method most recently used is cryopreservation in liquid nitrogen, however this is an expensive and labor-intensive procedure (Ercole et al. 2013).

Similar studies (Homolka 2014, Saha et al. 2014, Yooyongwech et al. 2019) have shown that encapsulation prior to the storage of microorganisms at low temperatures, presents benefits such as space and required maintenance reduction, stability of genetic material, protection against biotic and abiotic stress (Vemmer \& Patel 2013), and also improves their viability which can later contribute to the host plant species (Lalaymia et al. 2014, Pacheco et al. 2017). Furthermore, encapsulation of microorganisms can facilitate reintroduction strategies by facilitating transportation and handling of the different symbionts used to reintroduce orchids (Saiprasad \& Polisetty 2003).

In Ecuador, even though it is one of the hot spots with the greatest diversity of orchids in the world (Pérez-Escobar et al. 2017), there are no records regarding the encapsulation of mycorrhizal fungi, however this encapsulation technique has been used for microorganisms (Ercole et al. 2013, Vemmer \& Patel2013), seeds (Kulus \& Zalewska 2014, Pierce \& Belotti 2011), and as a mixture of both as well (Sommerville et al. 2008, Wood et al.2000). Encapsulation is a process with multiple applications in various industries (Vemmer \& Patel 2013), usually involving the use of sodium alginate at concentrations ranging from 1.5 to $3.5 \% \mathrm{v} / \mathrm{v}$ (Rodríguez et al. 2011).

The aims of the present work were: 1) to evaluate the viability of Ceratobasidium over time after storage at different temperatures in beads dried under different conditions 2) to evaluate encapsulation as an appropriate method to promote orchid-fungi symbiosis and thus a better survival and development of plants in substrate, since it is imperative that orchid conservation methods also deal with the preservation of associated fungi through simple field methods that promote plantfungi interaction.

Materials and methods. The fungi used in this study was Ceratobasidium sp. Rogers (1935), which was previously isolated from the rhizosphere of a Trichoceros antennifer (Humb. \& Bonpl.) Kunth. (1816) plant, its germination-promoting activity was verified in symbiotic germination tests and its identity was determined by molecular techniques. Genomic DNA was extracted from mycelia using Cenis (1992) method. As for the sequencing, the ITS regions were amplified with polymerase chain reaction (PCR) with the primers ITS1 and ITS4 (White et al. 1990). For molecular identification of the isolate, taxonomic assignments were made comparing the nucleotide sequences obtained with those deposited in the GenBank databases of the NCBI (National Center for Biotechnology Information).

The strain was re-isolated from plants used in a previous symbiotic germination test. For this, a portion of the root of plants grown by symbiotic germination and maintained under in vitro conditions was transferred to potato dextrose agar medium (PDA) at room temperature $\left(20 \pm 2^{\circ} \mathrm{C}\right)$. The cultures were multiplied several times by placing $0.25 \mathrm{~cm}^{2}(0.5 \times 0.5 \mathrm{~cm})$ of PDA fungal culture on fresh PDA plates.

Encapsulation.- The encapsulation process was performed by ion gelation using the Nisco brand EncapsulatorVar DBasic2Go LIN-0227 with a syringe pump. Preliminary tests were carried out on the equipment for the optimization of conditions and sodium alginate concentrations.

Encapsulation was done using a $0.5 \mathrm{~mm}$ nozzle, at $100 \%$ pump force, $5 \mathrm{ml} / \mathrm{min}$ flow, $0.5 \mathrm{kHz}$ frequency, $50 \%$ amplitude, $0,7 \mathrm{~mm} \pm 2 \mathrm{~mm}$ drop height, $83.3 \pm 0.1$ $\mu \mathrm{L}$ bead volume at an operating temperature of $25^{\circ} \mathrm{C}$.

Prior to operation, the encapsulator was disinfected by pumping $20 \mathrm{ml}$ of $1 \%$ sodium hypochlorite solution followed by three rinses with sterile distilled water.

For the elaboration of beads, we used the mycelium collected from half a PDA Petri dish $(90 \mathrm{~mm})$ 
grown for 10 days at room temperature. After the mycelium was collected it was placed in $5 \mathrm{ml}$ of $3 \%$ sterile sodium alginate and homogenized on a magnetic stirrer at $300 \mathrm{rpm}$ for 1 hour. The mixture was then placed in a $20 \mathrm{ml}$ syringe and injected into the encapsulator. Drops fell in a sterile $100 \mathrm{mM}$ calcium chloride $\left(\mathrm{CaCl}_{2}\right)$ solution, which was kept stirring for 10 minutes.

Afterwards, the $\mathrm{CaCl}_{2}$ solution was drained, leaving only the small beads. The beads were then divided into two groups. One group was placed in a sterile 0.75 M sucrose solution for osmotic dehydration for 22 hours at $130 \mathrm{rpm}$, and then air dried over tissue paper in a laminar flow hood continuously for 18 hours. The other portion of beads were placed directly inside the laminar flow hood for drying for $18 \mathrm{~h}$.

Two post-encapsulation processes were tested (sucrose dehydration + air drying and only air drying).

Storage and in vitro viability test. - to assess fungal viability after encapsulation, five beads from each treatment were placed individually within $90 \mathrm{~mm}$ Petri dishes filled with potato agar dextrose (PDA), and then incubated at room temperature $\left(20 \pm 2{ }^{\circ} \mathrm{C}\right)$ as a control treatment. The remaining beads from each treatment were divided into four groups to be stored in sterile vials al at $-80{ }^{\circ} \mathrm{C},-20{ }^{\circ} \mathrm{C}, 4{ }^{\circ} \mathrm{C}$ and at room temperature $(20$ $\pm 2{ }^{\circ} \mathrm{C}$ ) for the evaluation of their viability after $4,8,26$ and 96 weeks of storage. For this, five beads from each treatment were placed individually in a Petri dish containing PDA, and the viability of the fungi was recorded after five days, also, the mycelium growth was registered by measuring the diameter of mycelium. The data was analyzed by $\mathrm{R}$ version 4.1.1 to determine statistical differences $(\mathrm{p}<0.05)$ between storage times, drying treatment, and storage temperatures.

Symbiosis evaluation using encapsulates for inoculation under greenhouse conditions. - Fifty T. antennifer plants of a year and a half of age, were previously cultivated in vitro by the company Ecuagenera Cia. Ltda. were used for the test. The plants had variable sizes between 0.9 and $2.5 \mathrm{~cm}$, and each plant was weighed and measured from the stem to the apex of the youngest leaf. The roots were washed with sterile distilled water and finally the plants were placed in plastic trays containing pine bark previously treated by the same com- pany (cooked with lime and then washed until tannins are removed). Two beads containing the encapsulated fungi were placed in a total of 25 plants at a depth of one centimeter and very close to the root. The beads used were those that demonstrated their viability after 26 weeks of storage. The other 25 plants were grown under the same conditions, but no beads were placed in the soil, and thus constituted the control group.

All the plants were kept under a greenhouse, at around $20{ }^{\circ} \mathrm{C}$ and relative humidity of around $75 \%$. Irrigation was carried out once a week, fertilizer Ecuagrow $\left(\mathrm{NH}_{4} \mathrm{NO}_{3} 13 \%,\left(\mathrm{NH}_{4}\right) \mathrm{H}_{2} \mathrm{PO}_{4} 13 \%, \mathrm{KNO}_{3} 13 \%\right.$, $\mathrm{MgSO}_{4} 0.04 \%, \mathrm{CuSO}_{4} 0.03 \%, \mathrm{H}_{3} \mathrm{BO}_{3} 0.002 \%$ and polyolefin $5.5 \%$ ) was applied thirty days after being planted in the substrate and every three months after the first fertilization. After 10 months, the number of live plants in each treatment (with and without fungi) was determined. From the plants that were alive, five were taken randomly from each group and were weighed and measured once again. The obtained data was analyzed with $\mathrm{t}$-student test in $\mathrm{R}$ software version 4.1.1. To verify the presence of pelotons in the roots, a root tip sample was taken from each plant, cut into $0.5 \mathrm{~cm}$ segments and crushed using forceps, scalpel, and a little water. It was then observed under an Olympus SZ61 stereoscope at $4 \mathrm{X}$ and 10X magnification.

\section{Results. Storage and in vitro viability test.-}

After 4 and 8 weeks. - fungal growth was observed in all storage temperatures $\left(-80{ }^{\circ} \mathrm{C},-20{ }^{\circ} \mathrm{C}, 4{ }^{\circ} \mathrm{C}\right.$ and at room temperature $\left(20 \pm 2{ }^{\circ} \mathrm{C}\right)$ in both post-encapsulation treatments which were a) sucrose dehydration + air dried and b) only air dried.

After 26 weeks. - the beads were tested again to verify their viability, fungal growth was observed under $-80{ }^{\circ} \mathrm{C},-20{ }^{\circ} \mathrm{C}$ and $4{ }^{\circ} \mathrm{C}$ storage temperatures in both post-encapsulation treatments, after five days of being placed in a sterile PDA Petri dish. At room temperature only the air-dried beads showed fungal growth and no growth was shown in the beads treated with sucrose + air drying at day five, however on the $8^{\text {th }}$ day half of the beads presented fungal growth.

After 96 weeks. - the viability of fungi was registered again in $-80{ }^{\circ} \mathrm{C},-20^{\circ} \mathrm{C}$ and $4{ }^{\circ} \mathrm{C}$ storage temperatures but there was no growth in the beads stored at room temperature in any of the drying treatments, even after 10 days after being placed in petri dishes (Fig. 1A-B). 

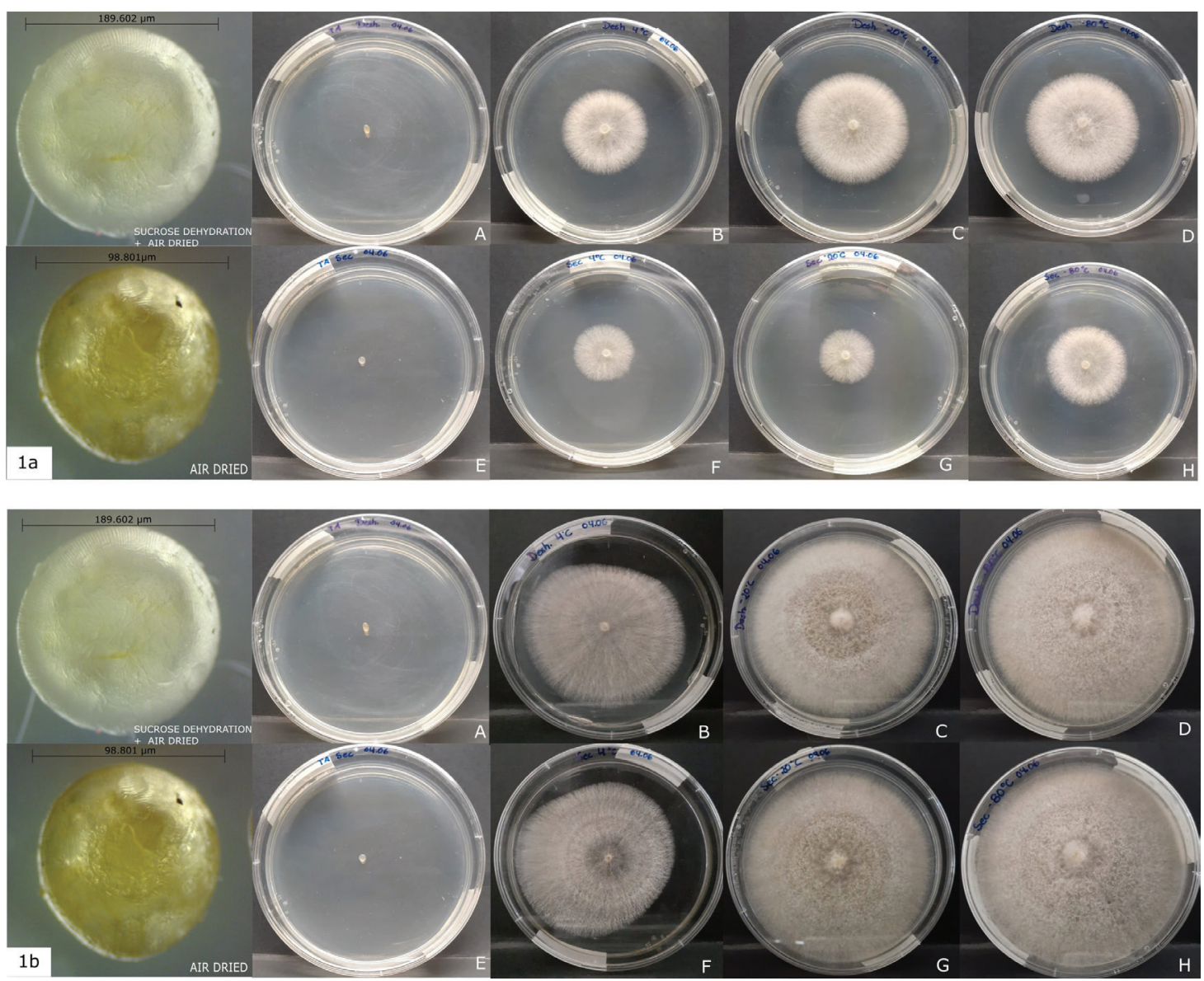

FIGURE 1. Viability of the fungi after 96 weeks of storage at different temperatures. 1a. 5 days after sowing (A-D sucrose dehydration + air dried Bead length=189.602 $\mu \mathrm{m})($ E-H only air dried Bead length= $98.801 \mu \mathrm{m})$. 1b. 10 days after sowing. Photographs by Diana Curillo.

In general, the growth of the fungi was more vigorous in the beads treated with sucrose + air-dried in the first five days. Additionally, the samples stored at $4^{\circ} \mathrm{C}$ showed comparatively less mycelial growth than the treatments stored at $-20{ }^{\circ} \mathrm{C}$ and $-80^{\circ} \mathrm{C}$ after 10 days of growth (Fig. 1B)

The mycelial radial growth of Ceratobasidium was significantly larger $(\mathrm{p}<0.05)$ at 26 weeks of storage than 96 weeks (Fig. 2). The data analyzed also revealed differences $(\mathrm{p}<0.05)$ between the drying methods observing a greater mycelium growth in sucrose dehydrated beads + air drying (Fig. 1A, 2). Finally significant differences were found between the growth radio at a temperature of $4{ }^{\circ} \mathrm{C}$ and the storage temperatures of $-20{ }^{\circ} \mathrm{C}$ and $-80{ }^{\circ} \mathrm{C}$ with the same drying treatment (Fig. 1B).
Symbiosis evaluation using encapsulates for inoculation under greenhouse conditions.- In the group of plants that received the treatment with the beads containing the fungi, 14 live plants were registered, representing a survival rate greater than $50 \%$, while in the control group, only 8 live plants were registered, which is about a $30 \%$ survival rate.

The average weight increase in the evaluated plants was $0.6 \mathrm{~g}$ for those who were inoculated in the beads and $0.3 \mathrm{~g}$ for the control group. The average height increase was $0.8 \mathrm{~cm}$ and $0.4 \mathrm{~cm}$ for the plants with and without fungi, respectively. As the data was analyzed it confirmed a statistically significant difference $(p<0.05)$ in weight and height, between the control group and plants inoculated with the beads (Fig. 3) 


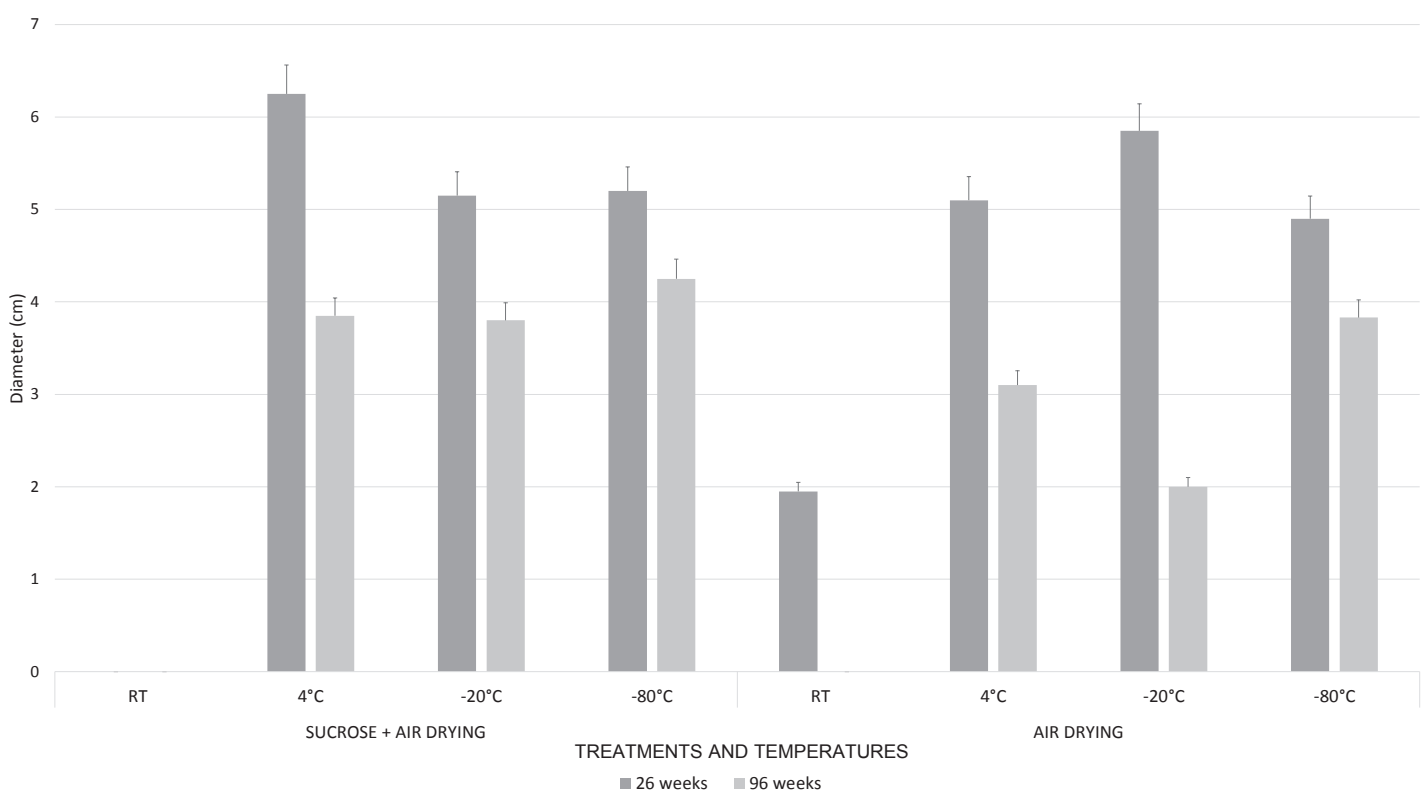

FiguRE 2. Mycelium growth of encapsulated Ceratobasidium in alginate beads after stored for 26 and 96 weeks at different temperatures, five days after sowing. Bars represent the mean \pm standard error $(n=5)$.

Regarding the presence of pelotons, these could be observed in 4 of the 5 plants belonging to the experimental group (Fig. 4A-4B), meanwhile, no pelotons were observed for the control group.

Discussion. The results suggest that encapsulation in alginate beads might be a viable strategy for the conservation of Ceratobasidium for up to a period of about two years (96 weeks) at temperatures of 4, -20 and -80 ${ }^{\circ} \mathrm{C}$ and with the possibility of storage for longer periods. However, according to our results storage at room temperature is not viable after 26 weeks, and these results were similar to those reported by Kim et al. (2019), who showed low viability after six months of storage, and the complete loss of viability after longer periods of storage at $37{ }^{\circ} \mathrm{C}$, showing that the viability of the fungal growth depends on the storage temperature of the beads.

Among the drying treatments following encapsulation, we observed that samples that underwent dehydration with sucrose showed lower viability after storage at room temperature for 26 weeks, which suggest that the air-drying treatment might be a favorable when the beads are stored in room temperature $\left(20 \pm 2{ }^{\circ} \mathrm{C}\right)$ for up to 26 weeks, However, there were no differences in the fungi viability between the other temperatures or stor- age periods. Similar results were obtained by Sommerville et al. (2008), who suggested that the sucrose used during the drying treatment provides an instant food source for the fungi encapsulated, which would explain the registered difference in our results after 26 weeks of storage at room temperature because the fungi remains active and keeps consuming its food source. The loss of viability $(50 \%)$ of the fungi inside the dehydrate beads with sucrose and kept at room temperature for 26 weeks matches the results reported by Sommerville et al. (2008) in which they registered minimal or no in vitro fungal growth of the beads dried with sucrose after being stored at room temperature for three months.

Likewise, the greater growth diameter of the mycelium of the fungus in the pearls treated with sucrose + drying, can also be explained since an immediate source of food is available when the fungus is reactivated as soon as the beads are removed from the different storage temperatures, which does not happen with those beads subjected to only to air drying. The differences recorded between the mycelium growth diameters at 26 weeks and then at 96 weeks could be associated with the handling of the material during the establishment of the trials, because the pearls that were not seeded at 26 weeks could have suffered an effect of thawing and re-freezing by being in the same conLANKESTERIANA 21(3). 2021. (C) Universidad de Costa Rica, 2021. 

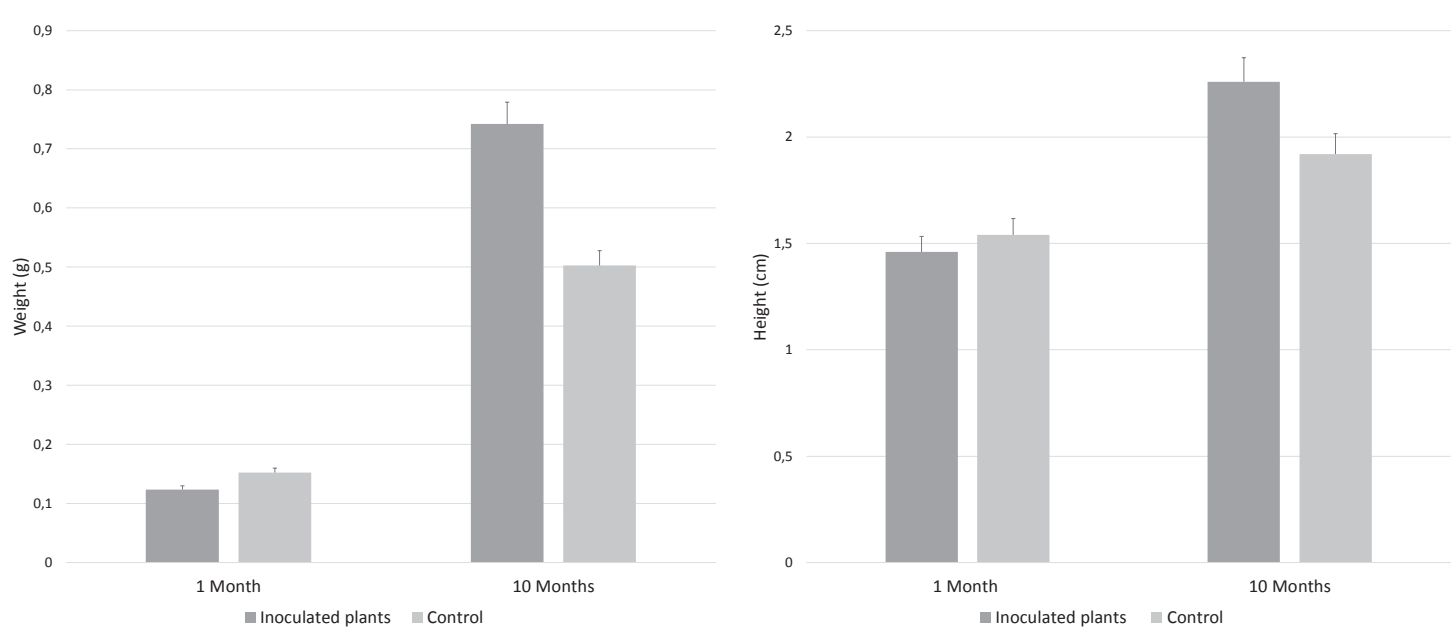

FIGURE 3. Effect of encapsulated Ceratobasidium beads in the weight and height of T. antennifer plants. Bars represent the mean \pm standard error $(n=5)$.
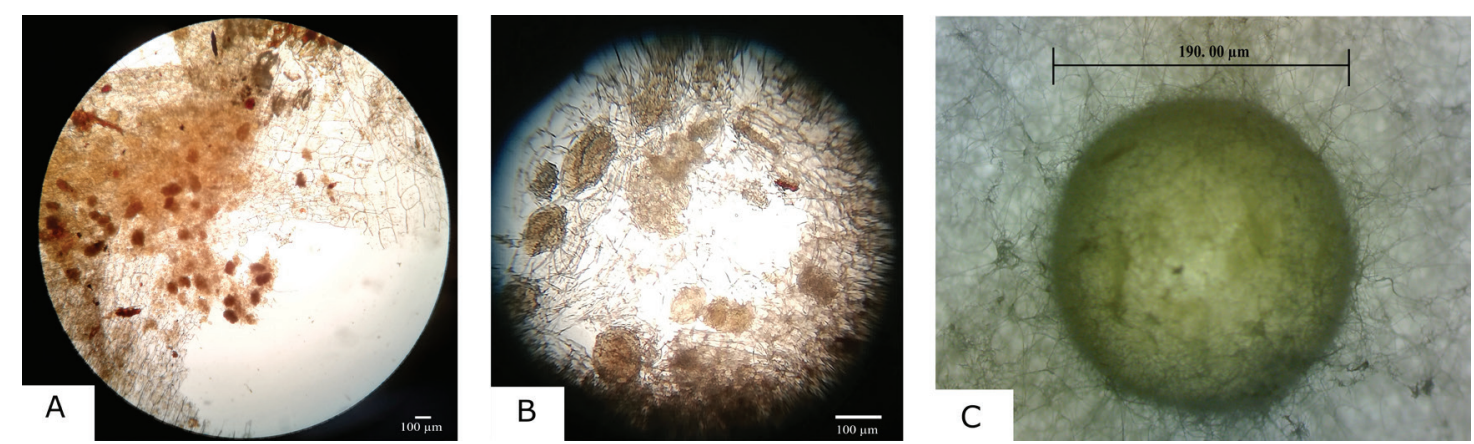

FIgURE 4. Presence of pelotons in plant roots. A. 4X magnification. B. 10X magnification. C. growth of hyphae from alginate beads in PDA medium. Photographs by Cesar Castro (A, B) and Diana Curillo (D).

tainer, however, the difference was reflected only in the mycelium development diameter, but not in its viability, which we interpret as a more vigorous growth.

In contrast to the work of Sommerville et al. (2008) we encapsulated the fungus alone (without including orchid seeds), which could be more convenient, since the parameters to be optimized during the process would focus on a single species. The results of our pilot study allowed to verify the symbiosis during the adaptation stage of the plants using encapsulates only of the fungus, which suggests that this method could be a good strategy to induce symbiosis.

Continuous recultivation could promote the adaptation of the fungi to laboratory conditions, with an impact on the genetic stability of new generations (Declerck et al. 2005).

Still the use of alginate beads could be considered as an alternative for the trade of other fungi of interest, since it has been reported that the storage of arbuscular mycorrhizal fungi in peat substrate decreases their infectivity over periods of time (Püschel et al. 2014). Lately, Zettler and Dvorak (2021) has published the efficiency of Tulasnella colospora (UAMH 9824) improve symbiotic germination after two decades of subculture, this argues against the concept of mycorrhizal fungi losing their symbiotic capacity after long periods of time of subcultures. In our study we verified the symbiosis in greenhouse conditions after inoculating orchids with Ceratobasidium that were previously stored for 26 weeks, demonstrating that the encapsulation method is not only efficient as a way to preserve the viability of the fungi but it also preserves its symbiotic capacity.

The preservation in alginate capsules allows easy handling field conditions and laboratory tests, because little space is required for their transportation and storage, the manipulation is simple, facilitates in- 
oculation, quantification and protection of the fungi. In addition, it is an easy to implement technique and, although we used dedicated encapsulating equipment, the latter is not essential and could be done using standard pipettes normally found in most laboratories (Plenchette \& Strullu 2003).

In conclusion, our evidence suggests that the storage of Ceratobasidium in alginate beads is an efficient storage method that allows the recovery of the fungi after 26 weeks at room temperature dried with air drying treatment and up to 2 years in a common refrigerator set at $4^{\circ} \mathrm{C}$ as well as in freezers set at -20 and $-80^{\circ} \mathrm{C}$.

Regarding the post encapsulation treatment, the dehydration with sucrose + drying with air flow, presented less viability after 26 weeks of storage at room temperature, but had no significant effect in its viability on the other temperatures $\left(4,-20,-80^{\circ} \mathrm{C}\right)$ or storage times (26 and 96 weeks). The growth diameter of the mycelium decreased after 96 weeks of storage at $4^{\circ} \mathrm{C}$ regardless of whether or not they are treated with sucrose, suggests an effect of the storage temperatures. It was also observed that sucrose accelerates growth during the first days of reactivation of the fungus at any of the evaluated temperatures. We also report that the capsules dried with sucrose + air flow are larger and easier to manipulate in the laboratory, if tweezers are used, while the pearls with just the drying treatment are much smaller, harder, and drier and could be more appropriate for inoculation in the field, however both could be used in the field and in the laboratory.

This methods for Ceratobasidium conservation could be replicable in other fungi of interest and has been suggested as a promising strategy for the developing large-scale fungal inoculation experiments and for the maintenance of collections (Plenchette \& Strullu 2003).

AcKNowledGMENTS. This project was funded by internal competitive funds from the University of Cuenca through project "Establecimiento de un banco de germoplasma de orquídeas nativas del sur del Ecuador y hongos micorrízicos asociados a ellas" under research permits 121-2016-DPAA/ MA granted by the National Biodiversity Direction of the Ecuadorian Ministry of the Environment. We express our sincere gratitude to Ecuagenera Cia. Ltda. for providing plants and facilities for the development of greenhouse work and Edison Lojano for their constant assistance. Finally, we acknowledge the VLIR Network Postgraduate Program.

\section{LITERATURE CITED}

Cenis, J. L. (1992). Rapid extraction of fungal DNA for PCR amplification. Nucleic Acids Research, 20(9), 2380-2380. https://doi.org/10.1093/nar/20.9.2380

Declerck, S., Séguin, S. \& Dalpé, Y. (2005). The Monoxenic Culture of Arbuscular Mycorrhizal Fungi as a Tool for Germplasm Collections. En S. Declerck, J. A. Fortin \& D.-G. Strullu (Eds.), In Vitro Culture of Mycorrhizas, Vol. 4 (pp. 17-30). Springer-Verlag. https://doi. org/10.1007/3-540-27331-X_2

Ercole, E., Rodda, M., Molinatti, M., Voyron, S., Perotto, S. \& Girlanda, M. (2013). Cryopreservation of orchid mycorrhizal fungi: A tool for the conservation of endangered species. Journal of Microbiological Methods, 93(2), 134-137. https://doi.org/10.1016/j.mimet.2013.03.003

Homolka, L. (2014). Preservation of live cultures of basidiomycetes-Recent methods. Fungal Biology, 118(2), 107-125. https://doi.org/10.1016/j.funbio.2013.12.002

Jiang, H., Chen, M.-C. \& Lee, Y.-I. (2017). In vitro germination and low-temperature seed storage of Cypripedium lentiginosum P.J.Cribb \& S.C.Chen, a rare and endangered lady's slipper orchid. Scientia Horticulturae, 225, 471-479. https://doi.org/10.1016/j.scienta.2017.07.040

Kim, J. C., Lee, M. R., Kim, S., Lee, S. J., Park, S. E., Baek, S., Gasmi, L., Shin, T. Y. \& Kim, J. S. (2019). Longterm storage stability of Beauveria bassiana ERL836 granules as fungal biopesticide. Journal of Asia-Pacific Entomology, 22(2), 537-542. https://doi.org/10.1016/j. aspen.2019.04.001

Kulus, D. \& Zalewska, M. (2014). In vitro plant recovery from alginate-encapsulated Chrysanthemum x grandiflorum (RAMAT.) KITAM. Shoot tips. Propagation of Ornamental Plants, 14(1), 3-12.

Lalaymia, I., Cranenbrouck, S. \& Declerck, S. (2014). Maintenance and preservation of ectomycorrhizal and arbuscular mycorrhizal fungi. Mycorrhiza, 24(5), 323337. https://doi.org/10.1007/s00572-013-0541-8

Pacheco, A., Ruíz, E., Ballina, S. \& Alvarado, J. (2017). Does polymer-based encapsulation enhance performance of plant growth promoting microorganisms? A meta-analysis view. Agrociencia, 51(2), 173-187.

Pérez-Escobar, O. A., Chomicki, G., Condamine, F. L., Karremans, A. P., Bogarín, D., Matzke, N. J., Silvestro, D. \& Antonelli, A. (2017). Recent origin and rapid speciation of Neotropical orchids in the world's richest plant biodiversity hotspot. New Phytologist, 215(2), 891-905. https://doi.org/10.1111/nph.14629

Pierce, S. \& Belotti, J. (2011). The Conservation of Terrestrial Orchids $\left(1^{\circ}\right)$. Italy: Parco delle Orobie Bergamasche and Centro Flora Autoctona della Regione Lombardia. 
Plenchette, C., \& Strullu, D.G. (2003). Long-term viability and infectivity of intraradical forms of Glomus intraradices vesicles encapsulated in alginate beads. Mycological Research, 107(5), 614-616. https://doi.org/10.1017/ S0953756203007482

Püschel, D., Rydlová, J. \& Vosátka, M. (2014). Can mycorrhizal inoculation stimulate the growth and flowering of peat-grown ornamental plants under standard or reduced watering? Applied Soil Ecology, 80, 93-99. https://doi.org/10.1016/j.apsoil.2014.04.001

Reiter, N., Whitfield, J., Pollard, G., Bedggood, W., Argall, M., Dixon, K., Davis, B. \& Swarts, N. (2016). Orchid re-introductions: An evaluation of success and ecological considerations using key comparative studies from Australia. Plant Ecology, 217, 81-95. https://doi. org/10.1007/s11258-015-0561-x

Rodríguez, C., Del Valle, E. M. M. \& Galán, M. A. (2011). Development of a new technique to generate microcapsules from the breakup of non-Newtonian highly iscous fluid jets. AIChE Journal, 57(12), 3436-3447. https:// doi.org/10.1002/aic

Saha, S., Sengupta, C. \& Ghosh, P. (2014). Molecular and phytochemical analyses to assess genetic stability in alginate-encapsulated microshoots of Ocimum gratissimum L. following in vitro storage. Nucleus (India), 57(1), 33-43. https://doi.org/10.1007/s13237-014-0107-y

Saiprasad, G. V. S. \& Polisetty, R. (2003). Propagation of three orchid genera using encapsulated protocormlike bodies. In Vitro Cellular \& Developmental Biology - Plant, 39(1), 42-48. https://doi.org/10.1079/ IVP2002360

Sommerville, K. D., Siemon, J. P., Wood, C. B. \& Offord, C. A. (2008). Simultaneous encapsulation of seed and mycorrhizal fungi for long-term storage and propagation of terrestrial orchids. Australian Journal of Botany, 56(7), 609-615.

Suárez, J. P. \& Kottke, I. (2016). Main fungal partners and different levels of specificity of orchid mycorrhizae in the tropical mountain forests of Ecuador. Lankesteriana, 16(2), 299-305.

Swarts, N. D. \& Dixon, K. W. (2009). Perspectives on orchid conservation in botanic gardens. Trends in Plant Science, 14(11), 590-598. https://doi.org/10.1016/j. tplants.2009.07.008
Teixeira da Silva, J. A., Tsavkelova, E. A., Zeng, S., Ng, T. B., Parthibhan, S., Dobránszki, J., Cardoso, J. C. \& Rao, M. V. (2015). Symbiotic in vitro seed propagation of Dendrobium: Fungal and bacterial partners and their influence on plant growth and development. Planta, 242(1), 1-22. https://doi.org/10.1007/s00425015-2301-9

van der Heijden, M. G. A., Martin, F. M., Selosse, M. A. \& Sanders, I. R. (2015). Mycorrhizal ecology and evolution: The past, the present, and the future. New Phytologist, 205, 1406-1423. https://doi.org/10.1111/ nph.13288

Vemmer, M. \& Patel, A. V. (2013). Review of encapsulation methods suitable for microbial biological control agents. Biological Control, 67(3), 380-389.

White, T. J., Bruns, T., Lee, S. \& Taylor, J. (1990). Amplification and direct sequencing of fungal ribosomal RNA genes for phylogenetics. In: M. A. Innis, D. H. Gelfand, J. J. Sninsky \& T. J. White (Eds.), PCR Protocols: $a$ guide to methods and applications (pp. 315-322). Elsevier. https://doi.org/10.1016/B978-0-12-3721808.50042-1

Wood, C. B., Pritchard, H. W. \& Miller, A. P. (2000). Simultaneous preservation of orchid seed and its fungal symbiont using encapsulation-dehydration is dependent on moisture content and storage temperature. Cryo-Letters, 21(2), 125-136.

Wraith, J. \& Pickering, C. (2018). Quantifying anthropogenic threats to orchids using the IUCN Red List. Ambio, 47(3), 307-317. https://doi.org/10.1007/s13280017-0964-0

Yooyongwech, S., Cha-Um, S., Tisarum, R., Therawitaya, C., Samphumphung, T., Aumtong, S., Kingkaew, J. \& Phisalaphong, M. (2019). Influence of different encapsulation types of arbuscular mycorrhizal fungi on physiological adaptation and growth promotion of maize (Zea mays L.) subjected to water deficit. Notulae Botanicae Horti Agrobotanici Cluj-Napoca, 47(1), 213-220. https://doi.org/10.15835/nbha47111249

Zettler, L. W. \& Dvorak, C. J. (2021). Tulasnella calospora (UAMH 9824) retains its effectiveness at facilitating orchid symbiotic germination in vitro after two decades of subculturing. Botanical Studies, 62(1), 14. https:// doi.org/10.1186/s40529-021-00321-w 